\title{
Virtual reality simulation in orthopaedic surgical training during periods of restricted clinical hours: a systematic review
}

\section{Bisola Salaja, ${ }^{a, b}, *$ Aoife Feeley, ${ }^{b}$ Iain Feeley, ${ }^{b}$ Eoin Sheehan ${ }^{b}$ and Khalid Merghani ${ }^{b}$}

${ }^{a}$ University of Limerick School of Medicine, Castletroy, Limerick, V94 T9PX, Ireland and ${ }^{b}$ Department of Orthopaedic Surgery, Midlands Regional Hospital Tullamore, Tullamore, Co. Offaly, Ireland

${ }^{*}$ Corresponding author at: University of Limerick School of Medicine, Castletroy, Limerick, Ireland. Email: btsalaja@hotmail.com

Date accepted for publication: 16 February 2021

\section{Abstract}

Background: The public health response to the coronavirus pandemic has imposed limitations on orthopaedic surgeons' scheduled care practice, with a consequential reduction in training time for residents within the specialty. A potentially viable option for maintenance of operative competency is the use of virtual reality (VR) surgical simulation. This review looks at the effectiveness of VR as a pedagogical method of learning for orthopaedic trainees. Question: Can VR be a viable method of learning and skill retention for orthopaedic trainees during periods of reduced operative time? Methods: A systematic search using Google Scholar, EMBASE and PubMed was conducted in July 2020. Results: Following the PRISMA guidelines, the initial search revealed 779 studies. Thirty-five full-text articles were analysed by two reviewers and a final total of 29 articles were included in this review. The levels of evidence ranged from one to four with variable quality. A thematic analysis revealed three broad categories: quality and validity of VR teaching simulations studies $(n=8)$; learning curves and subject performance papers $(n=14)$; usefulness of VR simulators in orthopaedics reviews $(n=7)$. Conclusion: We demonstrated that VR has the capacity to help trainees maintain their technical skills, enhance their precision and retain rudimentary competency during this pandemic. Additional developments are necessary to ensure its safety as a training tool. Although there are limited orthopaedic-specific VR simulators, surgical trainees can benefit from VR-based training when paired with other forms of orthopaedic education, such as cadaveric laboratories and simulation suites.

Keywords: virtual reality; orthopaedic training; simulations; COVID-19

\section{Introduction}

A number of pedagogical methods have been described in the formalization of surgical training and acquisition of operative skills, including Peyton's four-step approach and the Halstedian technique. ${ }^{1-3}$ These methods have a prerequisite of exposure to theatre and are predicated mainly on the actual operative caseload experienced by the trainee. The development of operative skills through experience in the operating room remains the primary mode of teaching, but with current guidelines in place, surgical trainees are forced to engage in distance learning. During the COVID-19 pandemic, orthopaedic surgeons have been obliged to postpone elective surgeries and to review their standard clinical schedules. With a reduction in theatre time, different pedological approaches have been explored, ${ }^{4}$ virtual reality (VR)based training in particular. In this review, we define VR as an interactive, computer-generated, simulated surgical procedure or skill acquisition programme.

VR has accompanied the continuing development of new technologies and surgical simulation devices. It allows trainees to remotely learn and augment their skills via virtual operative settings. Evidence on augmented surgical training with VR programmes has been well documented in various areas of surgery. Arroyo-Berezowsky et al. ${ }^{5}$ suggested specific orthopaedic educational goals that incorporate VR; they found it to be an accessible and safe method for trainees to learn new skills. Spicer at al. ${ }^{6}$ demonstrated VR to be a viable adjunct to traditional methods of teaching neurosurgical techniques, providing the technology continues to advance. Kim et al. ${ }^{7}$ established the potential of VR in plastic surgery, notably in surgical training, navigation and planning. 
Surgery is a physically technical field that requires its practitioners to engage in live scenarios to enhance and maintain their skills. ${ }^{8}$ The use of VR, online teaching seminars, surgical walkthroughs, at-home training, ${ }^{4,9-12}$ etc. appear to offer an educational and demonstrative avenue during these unique times. The question this review poses is whether VR is a viable method of learning and skill retention for surgical trainees during periods of restricted clinical hours. This systematic review looks at the efficacy of VR in orthopaedic surgical training to assess its potential benefits during this period of isolation. These results could also prove to be useful in a post-pandemic environment. An informal review of amendments that other institutions have put in place to combat this educational crisis was also carried out.

\section{Method}

\section{Study eligibility}

Articles were chosen initially based on titles and abstracts. These articles were reviewed by one author and duplicates and unavailable full texts were removed. Two authors then analysed each article based on the following criteria.

The inclusion criteria were as follows: (1) literature in English language; (2) level of evidence ranging between one and four based on the Oxford Centre for EvidenceBased Medicine 2011 Levels of Evidence; ${ }^{13}$ (3) VR used in all areas of orthopaedic surgery; (4) studies involving experienced and inexperienced orthopaedic surgeons; and (5) articles that included a segment on the usefulness of VR in orthopaedic surgery.

The exclusion criteria were as follows: (1) non-English articles; (2) articles focusing solely on augmented reality; (3) articles focusing exclusively on specialities other than orthopaedic surgery; (4) articles with only medical students as participants; (5) articles for which the full text was not available.

Educational commentaries on current orthopaedic teaching practices during the COVID-19 pandemic are mentioned in the review for references to current practices, not for secondary data.

\section{Search strategy}

This review began in July 2020 and it followed the Preferred Reporting Items for Systematic Reviews and Meta-Analyses (PRISMA) guidelines. ${ }^{14}$ The PRISMA flowchart is illustrated in Fig. 1. The Embase, Google Scholar and PubMed databases were searched using a combination of the following keywords: [virtual reality], [orthopaedic] [residents] and [covid].

\section{Data extraction}

Eligible articles were reviewed by two authors. A total of 29 articles were included in this review. Rayyan, ${ }^{15}$ a web app for systematic reviews, was used to aid in the selection. Summaries of each article used are given in Tables 1-3.

\section{Bias assessment}

Critical appraisal tools were used to assess each article's relevance and quality of results. Tools used included the Cochrane Risk of Bias assessment tool ${ }^{16}$ and the Joanna Briggs Institute Critical Appraisal checklists. ${ }^{17}$

\section{Results}

The search strategy yielded 779 results: 52 from Embase, 646 from Google Scholar, 79 from PubMed and two from other sources (colleague recommendations). On initial screening, after removal of duplicates and studies for which full text was not available, 35 articles remained: 16 studies from Embase, 14 from Google Scholar, four from PubMed, and one from other sources. These 35 articles were reviewed by two authors, and 29 articles were considered to meet the requirements for inclusion (Fig. 1).

\section{Thematic analysis}

Three broad themes were identified during the analysis of the literature on the use of VR in orthopaedic training. The first theme covers quality and validity of VR teaching simulations. Eight studies ${ }^{18-25}$ covered this area of research (Table 1). The second theme discusses learning curves and changes in performance using these simulations. A total of 14 papers $^{26-39}$ investigated this theme (Table 2). The third theme reports on reviews of orthopaedic VR simulators and evidence of their usefulness in orthopaedic training. Seven papers $^{40-46}$ analyse this topic (Table 3).

\section{Quality and validity of VR teaching simulations}

Studies have developed and/or studied VR simulations and their validity in areas of arthroscopy and arthroplasty in orthopaedic surgery. Vankipuram et al. ${ }^{18}$ designed and demonstrated the validity and performance of a VR drilling simulator. The construct validity of the TraumaVision (Swemac Orthopaedics, Linkoping, Sweden) simulator was established by Akhtar et al. ${ }^{19}$ Stunt et al. ${ }^{20}$ and Martin et al. $^{21}$ compared and verified the face and construct validity of shoulder and knee arthroscopic VR simulators; Bartlett et $\mathrm{al}^{24}$ demonstrated the face validity of a VR hip arthroscopy simulator. In spinal surgery, Shi et al. $^{23}$ found that the validity of the VR system they analysed was more accurate than conventional teaching methods. It was found to be a favourable alternative to traditional pedicle screw placement training. Gupta et al. ${ }^{22,25}$ developed a VR system for less 


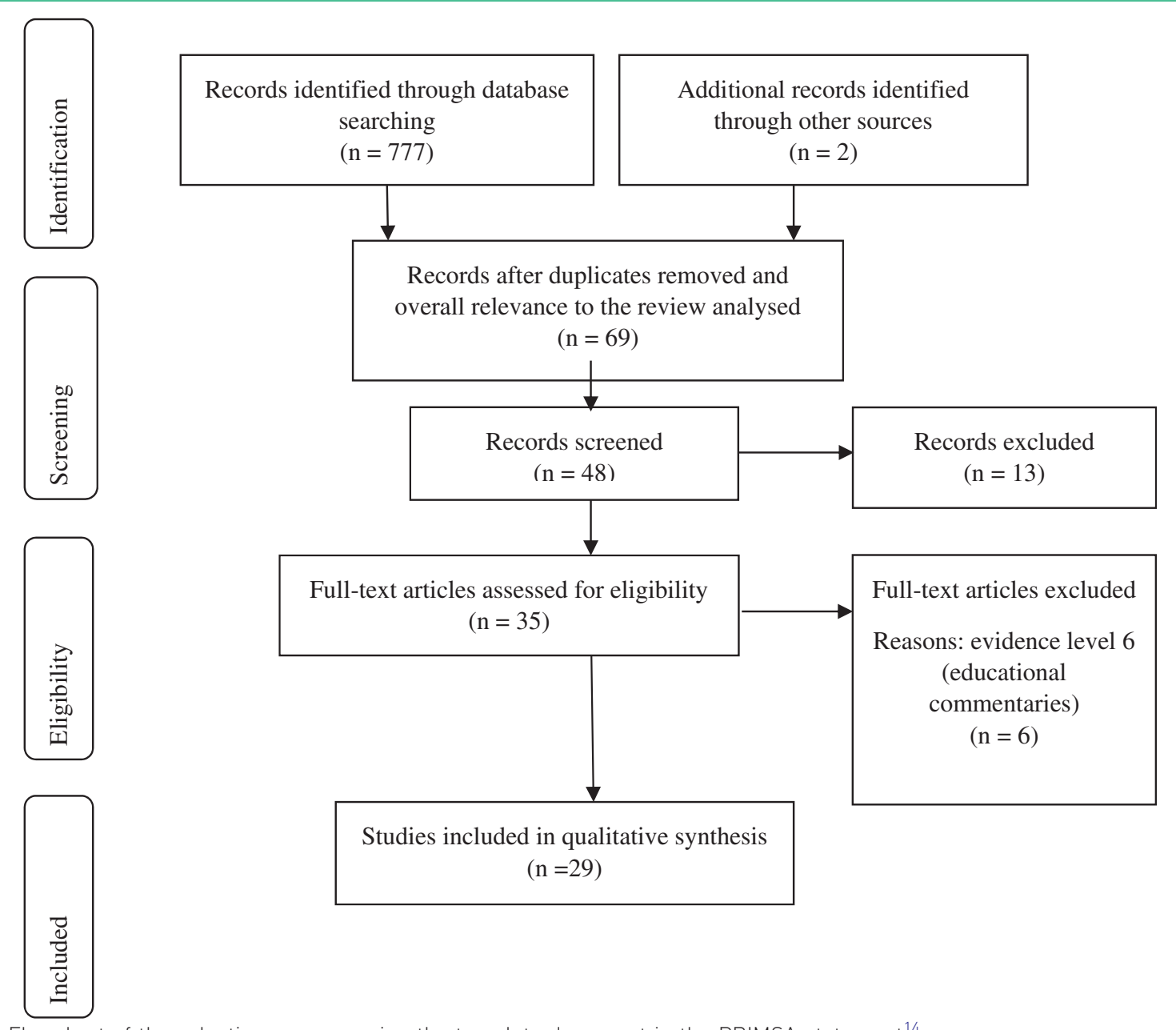

Figure 1. Flowchart of the selection process using the template document in the PRIMSA statement ${ }^{14}$

invasive stabilization system plating surgery, which is used in the repair of fractured femurs. The system was enhanced two years later ${ }^{25}$ and its validity was established.

\section{Learning curves and subject performance}

Subject abilities were tested in various areas of orthopaedic surgery, ranging from basic skills such as drilling, to more complex procedures such as total joint arthroplasty. Pedersen et al. ${ }^{27}$ found VR simulation-based examinations to be a valuable adjunct in assessing trainees in performing hip screws/nails. A pass/fail standard was discriminated between trainees and experts. Gustafsson et al. ${ }^{33}$ found a pass/fail standard score of $92 \%$ and established the learning curves of novices and experts. They also noted the importance of constant simulation-based training to a predefined standard in order to reap the true benefits of VR training. Both articles demonstrate a valid basic skill test, that has the potential to be utilized before trainees participate in live surgery with real patients.
Waterman et al. ${ }^{29}$ verified a transfer of skills from shoulder arthroscopy VR simulation to surgical skills in theatre. Residents who had VR-based training in Yari et al., ${ }^{32}$ made significant improvements in knee and shoulder arthroscopic surgical skills. Subjects in Gomoll et al. ${ }^{26}$ who had previously been tested using VR simulation 3 years previously, showed a significant improvement in their performance 3 years later. This further confirmed the use of VR simulation to evaluate surgical skills. ${ }^{26}$ They and Dammerer et al. ${ }^{30}$ recommend VR be used as a tool for teaching and improvement of technical surgical skills, mainly in anatomy and hand-eye coordination.

Studies with similar study designs agree on the advantages of VR in improving technical skills. ${ }^{34,38,39}$ Rahm et al. ${ }^{31}$ noted that VR-based training appears useful to learn camera handling, basic anatomy and triangulation with instruments. Notably with more challenging and precise procedures, such as pedicle screw placement, Xin et al. ${ }^{39}$ found a significant difference in success rate between 
Table 1. Quality and validity of virtual reality teaching simulations

\begin{tabular}{|c|c|c|c|c|c|}
\hline Reference & $\operatorname{Aim}(s)$ & $\begin{array}{l}\text { Total no. of } \\
\text { participants }\end{array}$ & $\begin{array}{l}\text { Participant } \\
\text { characteristics }\end{array}$ & Sample design & Conclusion \\
\hline Vankipuram et al., $2010^{18}$ & $\begin{array}{l}\text { Measure the validity of the } \\
\text { simulator using various } \\
\text { tests. Test its ability to dif- } \\
\text { ferentiate between experts } \\
\text { and novices }\end{array}$ & 33 & $\begin{array}{l}\text { Orthopaedic surgeons; } \\
\text { experts and residents; } \\
\text { novices }\end{array}$ & $\begin{array}{l}\text { Controlled labora- } \\
\text { tory study }\end{array}$ & $\begin{array}{l}\text { The multi-tiered testing strategy } \\
\text { showed that the simulator } \\
\text { was able to produce a learn- } \\
\text { ing effect that transfers to } \\
\text { real-world drilling. It was also } \\
\text { able to differentiate between } \\
\text { experts and novices }\end{array}$ \\
\hline Akhtar et al., $2015^{19}$ & $\begin{array}{l}\text { Evaluated the construct } \\
\text { validity of a new VR } \\
\text { trauma simulator for per- } \\
\text { forming dynamic hip screw } \\
\text { (DHS) fixation of a tro- } \\
\text { chanteric femoral fracture }\end{array}$ & 30 & Orthopaedic residents & $\begin{array}{l}\text { Non-randomized } \\
\text { controlled trial }\end{array}$ & $\begin{array}{l}\text { Proved construct validity of a } \\
\text { haptic VR DHS trauma } \\
\text { simulator. Results showed } \\
\text { that the surgeons who per- } \\
\text { formed this procedure regu- } \\
\text { larly also performed best on } \\
\text { the simulator. The detailed } \\
\text { level of objective feedback } \\
\text { provided by the simulator is } \\
\text { unavailable in the operating } \\
\text { theatre and provides precise } \\
\text { guidance on areas for } \\
\text { improvement }\end{array}$ \\
\hline Stunt et al., $2016^{20}$ & $\begin{array}{l}\text { Demonstrate face and con- } \\
\text { struct validity of the (prac- } \\
\text { tice Arthroscopic Surgical } \\
\text { Skills for perfect Operative } \\
\text { real-life Treatment) PASS- } \\
\text { PORT simulator }\end{array}$ & 31 & $\begin{array}{l}\text { Orthopaedic surgeons } \\
\text { (residents and experts); } \\
\text { researchers }\end{array}$ & $\begin{array}{l}\text { Non-randomized } \\
\text { controlled trial }\end{array}$ & $\begin{array}{l}\text { The simulator showed construct } \\
\text { and face validity, and its } \\
\text { physical nature offered ade- } \\
\text { quate haptic feedback during } \\
\text { training. This indicates that it } \\
\text { has potential to evolve as a } \\
\text { valuable training modality }\end{array}$ \\
\hline Martin et al., $2016^{21}$ & $\begin{array}{l}\text { Assess face validity of three } \\
\text { available VR simulators }\end{array}$ & 30 & $\begin{array}{l}\text { Orthopaedic residents; } \\
\text { medical students; } \\
\text { arthroscopy-trained } \\
\text { staff }\end{array}$ & $\begin{array}{l}\text { Single blinded ran- } \\
\text { domized con- } \\
\text { trolled trial }\end{array}$ & $\begin{array}{l}\text { ArthroS has the highest overall } \\
\text { face validity of the three cur- } \\
\text { rent arthroscopic VR simula- } \\
\text { tors. However, only external } \\
\text { appearance for ArthroS } \\
\text { reached statistical signifi- } \\
\text { cance when compared with } \\
\text { the other simulators. Each } \\
\text { simulator had satisfactory } \\
\text { intra-articular quality }\end{array}$ \\
\hline Cecil et al., $2017^{22}$ & $\begin{array}{l}\text { Propose that virtual reality- } \\
\text { based simulations can be } \\
\text { used to educate and train } \\
\text { surgical residents in target } \\
\text { surgical processes }\end{array}$ & 20 & $\begin{array}{l}\text { Orthopaedic surgeons } \\
\text { (experts and residents); } \\
\text { medical students }\end{array}$ & $\begin{array}{l}\text { Controlled labora- } \\
\text { tory study }\end{array}$ & $\begin{array}{l}\text { Most participants showed sig- } \\
\text { nificant improvements in } \\
\text { their understanding of the } \\
\text { Less Invasive Stabilization } \\
\text { System (LISS) plating surgical } \\
\text { process after interacting and } \\
\text { learning using the simulator }\end{array}$ \\
\hline Shi et al., $2018^{23}$ & $\begin{array}{l}\text { Assess the validity of a virtual } \\
\text { surgical training system on } \\
\text { lumbar pedicle screw pla- } \\
\text { cement for residents }\end{array}$ & 10 & $\begin{array}{l}\text { Orthopaedic residents } \\
\text { (inexperienced in } \\
\text { pedicle screw } \\
\text { implantation) }\end{array}$ & $\begin{array}{l}\text { Single blinded ran- } \\
\text { domized con- } \\
\text { trolled trial }\end{array}$ & $\begin{array}{l}\text { The virtual surgery simulation } \\
\text { with greater accuracy is } \\
\text { superior to the traditional } \\
\text { teaching methods in surgical } \\
\text { training of pedicle screw pla- } \\
\text { cement and can be used as a } \\
\text { promising alternative for } \\
\text { training of neurosurgical } \\
\text { procedures }\end{array}$ \\
\hline Bartlett et al., $2019^{24}$ & $\begin{array}{l}\text { To test the face validity of the } \\
\text { hip diagnostics module of a } \\
\text { virtual reality hip arthro- } \\
\text { scopy simulator }\end{array}$ & 50 & $\begin{array}{l}\text { Orthopaedic surgeons } \\
\text { (experts and residents); } \\
\text { faculty members }\end{array}$ & $\begin{array}{l}\text { Controlled labora- } \\
\text { tory study }\end{array}$ & $\begin{array}{l}\text { This VR hip arthroscopy simu- } \\
\text { lator was demonstrated to } \\
\text { have a sufficient level of rea- } \\
\text { lism, thus establishing its face } \\
\text { validity. These results suggest } \\
\text { this simulator has sufficient } \\
\text { realism for use in the acqui- } \\
\text { sition of basic arthroscopic } \\
\text { skills and supports its use in } \\
\text { orthopaedics surgical } \\
\text { training }\end{array}$ \\
\hline Gupta et al., $2019^{25}$ & $\begin{array}{l}\text { Discuss the adoption of } \\
\text { information-centric sys- } \\
\text { tems engineering (ICSE) } \\
\text { principles to design a } \\
\text { cyber-human systems- } \\
\text { based simulator framework } \\
\text { to train orthopaedic sur- } \\
\text { gery medical residents } \\
\text { using haptic and immersive } \\
\text { virtual reality platforms }\end{array}$ & 64 & $\begin{array}{l}\text { Orthopaedic residents; } \\
\text { medical students }\end{array}$ & $\begin{array}{l}\text { Controlled labora- } \\
\text { tory study }\end{array}$ & $\begin{array}{l}\text { Most participants showed sig- } \\
\text { nificant improvements in } \\
\text { their understanding of the } \\
\text { LISS plating surgical process } \\
\text { after interacting and learning } \\
\text { using the training simulators }\end{array}$ \\
\hline
\end{tabular}


Table 2: Learning curves and subject performance

\begin{tabular}{|c|c|c|c|c|c|}
\hline Reference & $\operatorname{Aim}(s)$ & $\begin{array}{l}\text { Total no. of } \\
\text { participants }\end{array}$ & Participant characteristics & Sample design & Conclusion \\
\hline Gomoll et al., $2008^{26}$ & $\begin{array}{l}\text { Prove that participants will show an } \\
\text { improved performance on simulator } \\
\text { retesting } 3 \text { years after an initial } \\
\text { baseline evaluation }\end{array}$ & 10 & $\begin{array}{l}\text { Orthopaedic surgeons (with } \\
\text { limited to no shoulder } \\
\text { arthroscopic experience) }\end{array}$ & $\begin{array}{l}\text { Controlled laboratory } \\
\text { study }\end{array}$ & $\begin{array}{l}\text { Participants significantly improved their } \\
\text { performance on simulator retesting } 3 \\
\text { years after initial evaluation }\end{array}$ \\
\hline Pedersen et al., $2014^{27}$ & $\begin{array}{l}\text { Develop a reliable and valid test with } \\
\text { credible pass/fail standards }\end{array}$ & 20 & $\begin{array}{l}20 \text { physicians (10 untrained } \\
\text { novices and } 10 \text { experi- } \\
\text { enced orthopaedic } \\
\text { surgeons) }\end{array}$ & $\begin{array}{l}\text { Single blinded non-ran- } \\
\text { domized controlled } \\
\text { trial }\end{array}$ & $\begin{array}{l}\text { The simulation-based test was reliable and } \\
\text { valid in the setting, and the pass/fail } \\
\text { standard could discriminate between } \\
\text { novices and experienced surgeons }\end{array}$ \\
\hline Camp et al., $2016^{28}$ & $\begin{array}{l}\text { Assess the efficacy of cadaveric skills } \\
\text { laboratories and virtual reality } \\
\text { simulator training methods, com- } \\
\text { pare their rates of improvement, and } \\
\text { provide economic value data to } \\
\text { programmes seeking to implement } \\
\text { such technologies }\end{array}$ & 45 & Orthopaedic residents & $\begin{array}{l}\text { Prospective randomized } \\
\text { controlled trial }\end{array}$ & $\begin{array}{l}\text { Cadaveric skills laboratories improved resi- } \\
\text { dents' performance of knee arthroscopy } \\
\text { compared with that of matched controls. } \\
\text { Residents practicing on cadaveric speci- } \\
\text { mens improved twice as fast as those } \\
\text { utilizing a high-fidelity simulator }\end{array}$ \\
\hline Waterman et al., $2016^{29}$ & $\begin{array}{l}\text { Simulation training would improve } \\
\text { residents' basic arthroscopic perfor- } \\
\text { mance and safety }\end{array}$ & 22 & Orthopaedic residents & $\begin{array}{l}\text { Single blinded, prospec- } \\
\text { tive randomized con- } \\
\text { trol trial }\end{array}$ & $\begin{array}{l}\text { Established transfer validity for an arthro- } \\
\text { scopic shoulder simulator model. } \\
\text { Additional simulation training improved } \\
\text { technical performance and patient safety } \\
\text { measures among residents compared } \\
\text { with a standard teaching curriculum }\end{array}$ \\
\hline Dammerer et al., $2018^{30}$ & $\begin{array}{l}\text { Analyse learning curves of medical } \\
\text { students and orthopaedic resident } \\
\text { surgeons using a virtual knee } \\
\text { arthroscopy simulator }\end{array}$ & 19 & $\begin{array}{l}\text { Orthopaedic residents; medi- } \\
\text { cal students }\end{array}$ & $\begin{array}{l}\text { Controlled laboratory } \\
\text { study }\end{array}$ & $\begin{array}{l}\text { Demonstrated the usefulness of the arthro- } \\
\text { scopy training simulator as an important } \\
\text { tool for improving surgical and arthro- } \\
\text { scopic skills in orthopaedic resident sur- } \\
\text { geons and medical students }\end{array}$ \\
\hline Rahm et al., $2018^{31}$ & $\begin{array}{l}\text { Tested the efficacy of a standardized, } \\
\text { competency-based training protocol } \\
\text { on a validated virtual reality-based } \\
\text { knee and shoulder arthroscopy } \\
\text { simulator }\end{array}$ & 25 & $\begin{array}{l}\text { Orthopaedic surgeons } \\
\quad \text { (experts and residents) }\end{array}$ & $\begin{array}{l}\text { Descriptive laboratory } \\
\text { study }\end{array}$ & $\begin{array}{l}\text { This sort of training method appears useful } \\
\text { to learn the handling of the camera, basic } \\
\text { anatomy and triangulation with } \\
\text { instruments }\end{array}$ \\
\hline Yari et al., $2018^{32}$ & $\begin{array}{l}\text { Determine the utility of the ArthroS } \\
\text { arthroscopic simulator for ortho- } \\
\text { paedic trainees based on their level } \\
\text { of training }\end{array}$ & 18 & Orthopaedic residents & $\begin{array}{l}\text { Descriptive laboratory } \\
\text { study }\end{array}$ & $\begin{array}{l}\text { Residents training on a virtual arthroscopic } \\
\text { simulator made significant improve- } \\
\text { ments in both knee and shoulder } \\
\text { arthroscopic surgery skills }\end{array}$ \\
\hline Gustafsson et al., $2019^{33}$ & $\begin{array}{l}\text { Determine the characteristics of learn- } \\
\text { ing curves for novices and experts } \\
\text { and establish a pass/fail mastery } \\
\text { learning standard for junior trainees }\end{array}$ & 46 & $\begin{array}{l}\text { Orthopaedic surgeons (first } \\
\text { year residents and } \\
\text { consultants) }\end{array}$ & $\begin{array}{l}\text { Controlled laboratory } \\
\text { study }\end{array}$ & $\begin{array}{l}\text { Training time to reach plateau varied widely } \\
\text { and it is paramount that simulation- } \\
\text { based training continues to a predefined } \\
\text { standard instead of ending after a fixed } \\
\text { number of attempts or amount of time }\end{array}$ \\
\hline Hooper et al., $2019^{34}$ & $\begin{array}{l}\text { Does the use of VR simulation improve } \\
\text { postgraduate year (PGY)-1 ortho- } \\
\text { paedic residents' performance in } \\
\text { cadaver total hip arthroplasty and its } \\
\text { beneficial effects on specific aspects } \\
\text { of surgical skills or knowledge }\end{array}$ & 14 & Orthopaedic residents & $\begin{array}{l}\text { Blinded randomized } \\
\text { controlled trial }\end{array}$ & $\begin{array}{l}\text { VR simulation improves PGY-1 resident } \\
\text { surgical skills but has no significant effect } \\
\text { on medical knowledge. The most signif- } \\
\text { icant improvement was seen in technical } \\
\text { skills }\end{array}$ \\
\hline Rölfing et al., $2019^{35}$ & $\begin{array}{l}\text { Investigate the role of failure in } \\
\text { repeated practice of virtual reality } \\
\text { (VR) simulation of hip fracture } \\
\text { surgery on cognitive load (CL) }\end{array}$ & 42 & Orthopaedic residents & $\begin{array}{l}\text { Controlled laboratory } \\
\text { study }\end{array}$ & $\begin{array}{l}\text { Reducing CL through instructional design } \\
\text { and handling of participant frustration } \\
\text { might improve the learning outcome of } \\
\text { simulation training programmes }\end{array}$ \\
\hline Lohre et al., $2020^{36}$ & $\begin{array}{l}\text { Determine the validity and efficacy of } \\
\text { immersive VR training in ortho- } \\
\text { paedic resident education }\end{array}$ & 26 & $\begin{array}{l}\text { Orthopaedic surgeons } \\
\quad \text { (experts and residents) }\end{array}$ & $\begin{array}{l}\text { Blinded, randomized } \\
\text { controlled trial }\end{array}$ & $\begin{array}{l}\text { Immersive VR demonstrated substantially } \\
\text { improved translational technical and } \\
\text { non-technical skill acquisition over tra- } \\
\text { ditional learning in senior orthopaedic } \\
\text { residents }\end{array}$ \\
\hline Walbron et al., $2020^{37}$ & $\begin{array}{l}\text { This study of residents' initial perfor- } \\
\text { mance was performed to determine } \\
\text { which factors predisposed residents } \\
\text { for success in demonstrating the } \\
\text { best arthroscopic skills }\end{array}$ & 116 & $\begin{array}{l}\text { Orthopaedic residents (1st } \\
\text { year) }\end{array}$ & $\begin{array}{l}\text { Prospective, compara- } \\
\text { tive, non-randomized } \\
\text { study }\end{array}$ & $\begin{array}{l}\text { This study shows a significant difference in } \\
\text { skills regarding spatial recognition and } \\
\text { triangulation related to gender at the } \\
\text { beginning of specialization training }\end{array}$ \\
\hline Walbron et al., $2020^{38}$ & $\begin{array}{l}\text { The primary aim was to compare var- } \\
\text { ious arthroscopy learning techni- } \\
\text { ques after } 6 \text { months of training }\end{array}$ & 107 & $\begin{array}{l}\text { Orthopaedic residents (1st } \\
\text { year) }\end{array}$ & $\begin{array}{l}\text { Prospective, compara- } \\
\text { tive, non-randomized } \\
\text { study }\end{array}$ & $\begin{array}{l}\text { The residents who participated in the VR } \\
\text { arthroscopy simulator training pro- } \\
\text { gramme for } 6 \text { months had better results } \\
\text { when performing practical exercises and } \\
\text { standard arthroscopy tasks. Their final } \\
\text { performance indicated technical mastery } \\
\text { that the other residents had not achieved }\end{array}$ \\
\hline Xin et al., $2020^{39}$ & $\begin{array}{l}\text { To verify whether the pedicle screw } \\
\text { placement (PSP) skills of young } \\
\text { surgeons receiving immersive vir- } \\
\text { tual reality surgical simulator } \\
\text { (IVRSS) training could be improved } \\
\text { effectively and whether the IVRSS- } \\
\text { PSP training mode could produce a } \\
\text { real clinical value in clinical surgery }\end{array}$ & 24 & $\begin{array}{l}\text { Orthopaedic surgeons } \\
\quad \text { (attendings }<1 \text { year) }\end{array}$ & $\begin{array}{l}\text { Randomized double- } \\
\text { blind controlled trial }\end{array}$ & $\begin{array}{l}\text { Demonstrated that IVRSS-PSP was helpful } \\
\text { to improve the success rate of PSP for } \\
\text { young surgeons and may provide valu- } \\
\text { able reference for PSP training of young } \\
\text { surgeons. Study also showed a promising } \\
\text { potential of the VR technology in surgical } \\
\text { simulation training }\end{array}$ \\
\hline
\end{tabular}


Table 3. Evidence of the usefulness of VR simulators in orthopaedics

\begin{tabular}{|c|c|}
\hline Reference & $\operatorname{Aim}(s)$ \\
\hline Mabrey et al., $2010^{40}$ & $\begin{array}{l}\text { (1) How has VR worked for } \\
\text { other surgical specialties; (2) } \\
\text { what VR solutions are avail- } \\
\text { able for orthopaedics; and (3) } \\
\text { should VR simulation } \\
\text { become part of the ortho- } \\
\text { paedic curriculum? }\end{array}$ \\
\hline Vaughan et al., $2016^{41}$ & $\begin{array}{l}\text { Present existing virtual reality- } \\
\text { based training simulators for } \\
\text { hip, knee and other ortho- } \\
\text { paedic surgery, including } \\
\text { elective and trauma surgical } \\
\text { procedures }\end{array}$ \\
\hline
\end{tabular}

Pfandler et al., $2017^{42}$

Examine the existing research on VR-based simulators in spinal procedures. Assess the quality of current studies evaluating VR-based training in spinal surgery

Bartlett et al., $2018^{43}$

To assess the current evidence relating to the benefits of virtual reality (VR) simulation in orthopaedic surgical training, and to identify areas of future research

Fritz et al., $2019^{44}$

$$
\begin{aligned}
& \text { A review of surgical training } \\
& \text { programmes and their } \\
& \text { methods of training }
\end{aligned}
$$

Hedman et al., $2020^{45}$ For a growing number of minimally invasive and technically challenging orthopaedic procedures, there is a movement to improve surgical skills training outside the operating room because of, e.g. patient safety concerns. Surgical simulation is a powerful tool that can help meet these training demands

Negrillo-Cárdenas
et al., $2020^{46}$ Analysis of the impact of virtual and augmented reality to bone fracture healing, detailing each task from diagnosis to rehabilitation

$\begin{array}{llll}\begin{array}{l}\text { Total no. of } \\ \text { participants }\end{array} & \begin{array}{l}\text { Participant } \\ \text { characteristics }\end{array} & \text { Sample design } & \text { Conclusion }\end{array}$

N/A N/A Literature review VR simulators are readily available

for shoulder and knee arthroscopy

but not as well incorporated into training curricula. Orthopaedic training programmes should take advantage of the commercially available VR simulators for orthopaedic procedures

N/A N/A Systematic review Few training simulators are available for hip replacement, yet more advanced virtual reality is being used for other procedures such as hip trauma and drilling. This suggests there is a gap in the market for a new high-fidelity hip replacement and resurfacing training simulator

Systematic review

Higher-quality studies with patientrelated outcome measures are needed. To establish further adaptation of VR-based simulators in spinal surgery, future evaluations need to improve the study quality, apply long-term study designs, and examine non-technical skills, as well as multidisciplinary team training

Systematic review

Evidence supporting the usefulness of VR simulation in other forms of orthopaedic surgery is lacking. Further studies of validity and usefulness should be combined with robust analyses of the cost efficiency of validated simulators to justify the financial investment required for their use in orthopaedic training

N/A N/A Literature review

VR simulators have a training programme already implemented, which allows the trainee to perform the procedures with or without supervision by a trainer. They enable the training of complex procedures such as rotator cuff reconstruction

Literature review

When used appropriately, extended simulation training can be a highly effective additional training tool in the development and maintenance of technical skills and combatting skills decay, considering motivation and flow. This is relevant also for temporarily non-performing orthopaedic surgeons during a crisis affecting the organization of health care such as the COVID-19 pandemic

N/A N/A

Systematic review

We have noted that virtual reality is an appropriate technology to assist in pre-surgical tasks, mainly focusing on visualization in training systems. It also represents an excellent choice to treat several conditions or perform rehabilitation exercises 
trainees who had undergone VR-based training and those who did not. Lohre et al. ${ }^{36}$ was the only study that demonstrated an improvement in translational technical and nontechnical skills acquisition with VR-based training compared with traditional learning in senior orthopaedic residents.

Conversely, Camp et al. ${ }^{28}$ found that residents who trained on cadaveric specimens improved twice as fast as those who had VR-based training, for diagnostic knee arthroscopies. Rolfing et al..$^{35}$ noted participant frustration to be a barrier for simulation training programmes. Nevertheless, a cost analysis showed VR simulation to be more cost-effective if utilized properly.

\section{Evidence of the usefulness of VR simulators in orthopaedics}

Pfandler et al. ${ }^{42}$ and Bartlett et al. ${ }^{43}$ presented the benefits of VR-based training in improving technical skills and knowledge of surgical trainees. However, they noted a need for more high-quality randomized controlled trials, testing VRbased training's effectiveness in surgical performance. Fritz et al. $^{44}$ noted a key advantage of VR-based training where trainees can perform procedures and receive feedback such as precision, error rates and accuracy, without supervision by a senior. Mabrey et al. ${ }^{40}$ addressed the challenges of implementing surgical simulators in orthopaedic training; particularly, that the current simulators address a limited range of surgical skills. To implement them in a training curriculum, a "universal platform" with a variety of procedures would be favoured. Negrillo-Cárdenas et al. ${ }^{46}$ reported that VR-based training was useful for pre-surgical tasks, especially aiding in visualization. Vaughan et al. ${ }^{41}$ found that numerous VR simulators were targeted to hip trauma procedures, in contrast to the few hip arthroplasty simulators at the time (2015). Walbron et al. ${ }^{37}$ used VR simulation to determine which factors predisposed residents for success in demonstrating the best arthroscopic skills. They found their male residents had better spatial recognition and triangulation skills. They proposed introducing VR-based training earlier in training schemes to combat this discrepancy. One article mentioned the usefulness of VR-based training during the COVID-19 pandemic. Hedman et al. ${ }^{45}$ observed its usefulness in skill retention and maintenance, especially for orthopaedic surgeons who are not operating temporarily.

\section{Discussion}

There is increasing evidence of the potential VR has as an adjunct method of training for orthopaedic surgical trainees. The evidence of its effects in orthopaedic training is broad; from constructing and testing the validity of simulators to examining whether these skills are transferable in the theatre. The results are promising, although some of the studies were of lower quality than others and potentially biased.

\section{Shortcomings of VR training}

Our review discovered that training with cadaveric specimens surpassed VR-based training twofold. Camp et al. ${ }^{28}$ found that residents who trained using cadaveric specimens improved their arthroscopy skills twice as fast as those practising with VR-based simulation. Both groups practiced for 4 hours with their respective methods, but the cadaveric group was explicitly asked to develop their arthroscopic skills. This group also received simple instructions from a senior resident, i.e. mentoring, whereas the VR-trained group did not. The beneficial role of mentoring in improving surgery simulations scores was observed in a study by Lee et al. ${ }^{47}$. These points could account for the time discrepancy found in the study by Camp et al. ${ }^{28}$ Nevertheless, trainees do not necessarily have to learn as quickly as possible but rather safely and accurately.

In addition, Hooper et al. ${ }^{34}$ found that VR-based training had no significant effect on the medical knowledge of their residents. This indicated that VR simulations, although effective in the setting of novice learning, ${ }^{48}$ still lack an element of training that real anatomic specimens seem to provide. Mainly, our review revealed a dearth of evidence of the usefulness of VR in orthopaedic surgical training compared with other specialities. ${ }^{49}$ Among the limited orthopaedic VR simulators, there appears to be a lack of various staple orthopaedic procedures; notably hip replacements. ${ }^{41}$

\section{Benefits of VR training}

The shortcomings of VR exposed the disparity of the usefulness of VR in orthopaedics; despite this, our review included multiple studies that had designed their own VR orthopaedic simulators. The creators involved in these training environments included expert orthopaedic surgeons who have insight on the needs of orthopaedic trainees to improve their surgical skills. Despite the novelty of these innovations, their validity was proven. These studies display a constructive attempt to fill the gap of the usefulness of VR-based training in orthopaedics. Only six articles included in this review had received some form of funding, i.e. doctoral grants or national grants. No articles disclosed funding directly linking them to the VR manufacturers used in their articles, suggesting funding bias to be a low possibility.

We found VR to aid in maintaining ${ }^{45}$ and improving technical surgical skills. ${ }^{34,42,43}$ This was observed to be beneficial during periods of restricted clinical hours. ${ }^{45}$ Fritz et al. ${ }^{44}$ 
demonstrated the benefits of technological feedback from VR simulators. Boyle et al. ${ }^{48}$ reinforced this point and noted significant improvement in surgical skills, especially in the setting of novice training, regardless of supervised feedback. We also found possible substitutes for the gaps in training. McKechnie et al. ${ }^{11}$ provided a succinct overview of the technologies available for surgical trainees to use domestically. They offered three computer-based platforms for orthopaedics: Ortho Oracle (International Business Machines Corporation Watson, London and Wales), AO Surgery Reference (AO Foundation, Switzerland) and the VR option in Fundamental Surgery (Fundamental VR, London). Ortho Oracle offers live and recorded videos on almost all subspecialties of orthopaedic surgery; AO Surgery Reference is a valuable resource for the management of numerous types of fractures. Overall, VR offers trainees the opportunity to practice their surgical skills at their own convenience. With the added ability to train at home, the work-life balance for orthopaedic trainees could be strengthened. Additional time to train may also result in a learning curve that is not as steep when starting to operate on live patients.

\section{Changes during the pandemic}

Other institutions have adapted to this pandemic by introducing online teaching seminars, cadaveric simulations, athome training, etc. They also considered how to integrate VR into their traditional teaching models during this pandemic. Plancher et al. ${ }^{4}$ noted its advantages of being more portable and more easily accessible than cadaveric training, allowing surgical trainees to practice distanced learning. Stambough et al. ${ }^{9}$ acknowledged that the post-COVID-19 environment will likely lead to an emphasis on VR advancement but mentions that it is lacking the necessary visual and tactile feedback needed to practise safe surgery. Davey et al. ${ }^{12}$ comments on the overnight changes the pandemic brought in the importance of orthopaedic training methods. Especially, how platforms that were previously believed supplementary quickly became crucial in response to the unprecedented COVID-19 pandemic. $^{11}$ Overall, these institutions agreed on two aspects: the necessity of more highquality VR-based training trials and the need for developments to ensure VR is a safe form of teaching.

VR-based training appears to provide a safe environment for orthopaedic surgical skill education. With or without guidance from experts, it allows for repeatability and reproducibility within a setting that minimizes risk to patients. Several articles acknowledge the necessity of repeatability in VR. We found that to gain its full benefits, trainees must practice regularly to match/overtake a standard score. Camp et al. ${ }^{28}$ determined for their VR simulation to be more cost- effective than cadaveric training, residents must practice at least 300 hours annually. The COVID-19 pandemic has provided orthopaedic residents with more free time for training on these simulations, therefore gaining from their educational value. Although there are limited orthopaedicspecific VR simulators, surgical trainees still benefit when VR is paired with other forms of orthopaedic training, primarily in improving technical surgical skills.

\section{Limitations}

Only three online databases were used for this review, resulting in evidence selection bias. No unpublished papers were found/included, which may have provided a more well-rounded outcome, leading to publication bias. The number of participants in each study varied ranging from ten to 116, with only six studies including 50 or more participants. The studies also included residents at different levels of training, mainly from the USA. As there is a significant difference in orthopaedic training between the USA and other countries, this limitation must also be considered.

\section{Conclusion}

VR simulation appears to be a favourable adjunct to training, both in times of a pandemic when the access to theatre is limited, and with restrictions to working hours. Therefore, it can act as an accelerator of development of surgical skills. We observed that it serves as an appreciated pedological adjunct in orthopaedic education and we have shown it has the capacity to help trainees maintain their technical skills, enhance their precision and retain rudimentary competency. It can provide the ability to practice and repeat procedures with less radiation exposure. Additional advancements still need to be made to ensure its safety as a training tool. Despite this, we anticipate that in time and with the input of expert surgeons, experienced technicians and software developers, VR simulations will eventually be a key part of orthopaedic training.

\section{Conflict of interests}

None declared.

\section{Acknowledgement}

This project was carried out with funding from the Medical Education Liaison Group (MELG) research awards. Successful recipients of this award received a bursary for completing their project. 


\section{References}

1. Feeley I, Kelly M, Healy E, Murray F, O’Byrne J. Surgical tuition within Irish hospitals: a national survey. Ir J Med Sci 2018; 187(1): 177-182. https://doi.org/10.1007/s11845017-1610-3.

2. Romero P, Günther P, Kowalewski K-F, Friedrich M, Schmidt MW, Trent SM, et al. Halsted's "see one, do one, and teach one" versus Peyton's four-step approach: a randomized trial for training of laparoscopic suturing and knot tying. J Surg Educ 2018; 75(2): 510-515. https://doi.org/10.1016/j.jsurg. 2017.07.025.

3. Gradl-Dietsch G, Lübke C, Horst K, Simon M, Modabber A, Sönmez TT, et al. Peyton's four-step approach for teaching complex spinal manipulation techniques-a prospective randomized trial. BMC Med Educ 2016; 16(1): 284. https://doi. org/10.1186/s12909-016-0804-0.

4. Plancher KD, Shanmugam JP, Petterson SC. The changing face of orthopaedic education: searching for the new reality after COVID-19. Arthrosc Sports Med Rehabil 2020; 2(4): e295-e298. https://doi.org/10.1016/j.asmr.2020.04.007.

5. Arroyo-Berezowsky C, Jorba-Elguero P, Altamirano-Cruz MA, Quinzaños-Fresnedo J. Usefulness of immersive virtual reality simulation during femoral nail application in an orthopedic fracture skills course. J Musculoskelet Surg Res 2019; 3(4): 326. https://doi.org/10.4103/jmsr.jmsr_78_19.

6. Spicer MA, Apuzzo ML. Virtual reality surgery: neurosurgery and the contemporary landscape. Neurosurgery 2003; 52(3): 489-498. https://doi.org/10.1227/01.NEU.0000047812.42726. 56.

7. Kim Y, Kim H, Kim YO. Virtual reality and augmented reality in plastic surgery: a review. Arch Plast Surg 2017; 44(3): 179. https://doi.org/10.5999/aps.2017.44.3.179.

8. Moorthy K, Munz Y, Sarker SK, Darzi A. Objective assessment of technical skills in surgery. BMJ 2003; 327(7422): 1032-1037. https://doi.org/10.1136/bmj.327.7422.1032.

9. Stambough JB, Curtin BM, Gililland JM, Guild GN 3rd, Kain MS, Karas V, et al. The past, present, and future of orthopedic education: lessons learned from the COVID-19 pandemic. J Arthroplasty 2020; 35(7S): S60-S64. https://doi.org/10.1016/j. arth.2020.04.032.

10. Kogan M, Klein SE, Hannon CP, Nolte MT. Orthopaedic education during the COVID-19 pandemic. J Am Acad Orthop Surg 2020; 28(11): e456-e464. https://doi.org/10. 5435/JAAOS-D-20-00292.

11. McKechnie T, Levin M, Zhou K, Freedman B, Palter VN, Grantcharov TP. Virtual surgical training during COVID-19: operating room simulation platforms accessible from home. Ann Surg 2020; 272(2): e153-e154. https://doi.org/10. 1097/SLA.0000000000003999.

12. Davey MS, Cassidy JT, Lyons RF, Cleary MS, Niocaill RFM. Changes to training practices during a pandemic - the experience of the Irish National Trauma \& Orthopaedic Training Scheme. Injury 2020; 51(10): 2087-2090. https://doi.org/10.1016/j.injury.2020.07.016.

13. OCEBM Levels of Evidence Working Group. The Oxford 2011 levels of evidence. Oxford Centre for Evidence-Based Medicine. Available from: http://www.cebm.net/index.aspx? $\mathrm{o}=5653$.

14. Moher D, Liberati A, Tetzlaff J, Altman DG, PRISMA Group. Preferred reporting items for systematic reviews and metaanalyses: the PRISMA statement. PLoS Med 2009; 6(7): e1000097. https://doi.org/10.1371/journal.pmed.1000097.

15. Ouzzani M, Hammady H, Fedorowicz Z, Elmagarmid A. Rayyan-a web and mobile app for systematic reviews. Syst Rev 2016; 5(1): 210. https://doi.org/10.1186/s13643016-0384-4.

16. Higgins JP, Altman DG, Gøtzsche PC, Jüni P, Moher D, Oxman $\mathrm{AD}$, et al. The Cochrane Collaboration's tool for assessing risk of bias in randomised trials. BMJ 2011; 343 : d5928. https://doi.org/10.1136/bmj.d5928.

17. JBI. Critical appraisal tools 2017. Available from: https://jbi. global/critical-appraisal-tools.

18. Vankipuram M, Kahol K, McLaren A, Panchanathan S. A virtual reality simulator for orthopedic basic skills: a design and validation study. J Biomed Informatics 2010; 43(5): 661668. https://doi.org/10.1016/j.jbi.2010.05.016.

19. Akhtar K, Sugand K, Sperrin M, Cobb J, Standfield N, Gupte C. Training safer orthopedic surgeons: construct validation of a virtual-reality simulator for hip fracture surgery. Acta Orthop 2015; 86(5): 616-621. https://doi.org/10. 3109/17453674.2015.1041083.

20. Stunt J, Kerkhoffs G, Horeman T, van Dijk C, Tuijthof G. Validation of the PASSPORT V2 training environment for arthroscopic skills. Knee Surg Sports Traumatol Arthrosc 2016; 24(6): 2038-2045. https://doi.org/10.1007/s00167014-3213-0.

21. Martin KD, Akoh CC, Amendola A, Phisitkul P. Comparison of three virtual reality arthroscopic simulators as part of an orthopedic residency educational curriculum. Iowa Orthop J 2016; 36: 20.

22. Cecil J, Gupta A, Pirela-Cruz M, Ramanathan P. A cyber training framework for orthopedic surgery. Cogent Med 2017; 4(1): 1419792. https://doi.org/10.1080/2331205X.2017. 1419792.

23. Shi J, Hou Y, Lin Y, Chen H, Yuan W. Role of visuohaptic surgical training simulator in resident education of orthopedic surgery. World Neurosurg 2018;111:e98-e104. https://doi. org/10.1016/j.wneu.2017.12.015.

24. Bartlett JD, Lawrence JE, Khanduja V. Virtual reality hip arthroscopy simulator demonstrates sufficient face validity. Knee Surg Sports Traumatol Arthrosc 2019; 27(10): 31623167. https://doi.org/10.1007/s00167-018-5038-8. 
25. Gupta A, Cecil J, Pirela-Cruz M, Ramanathan P. A virtual reality enhanced cyber-human framework for orthopedic surgical training. IEEE Syst J 2019; 13(3): 3501-3512. https://doi. org/10.1109/JSYST.2019.2896061.

26. Gomoll AH, Pappas G, Forsythe B, Warner JJ. Individual skill progression on a virtual reality simulator for shoulder arthroscopy: a 3-year follow-up study. Am J Sports Med 2008; 36(6): 1139-1142. https://doi.org/10.1177/0363546508314406.

27. Pedersen P, Palm H, Ringsted C, Konge L. Virtual-reality simulation to assess performance in hip fracture surgery. Acta Orthop 2014; 85(4): 403-7. https://doi.org/10. 3109/17453674.2014.917502.

28. Camp CL, Krych AJ, Stuart MJ, Regnier TD, Mills KM, Turner NS. Improving resident performance in knee arthroscopy: a prospective value assessment of simulators and cadaveric skills laboratories. J Bone Joint Surg Am 2016; 98(3): 220-225. https://doi.org/10.2106/JBJS.O.00440.

29. Waterman BR, Martin KD, Cameron KL, Owens BD, Belmont PJ. Simulation training improves surgical proficiency and safety during diagnostic shoulder arthroscopy performed by residents. Orthopedics 2016; 39(3): e479-e85. https://doi. org/10.3928/01477447-20160427-02.

30. Dammerer D, Putzer D, Wurm A, Liebensteiner M, Nogler M, Krismer M. Progress in knee arthroscopy skills of residents and medical students: a prospective assessment of simulator exercises and analysis of learning curves. J Surg Educ 2018; 75(6): 1643-1649. https://doi.org/10.1016/j.jsurg.2018.05.002.

31. Rahm S, Wieser K, Bauer DE, Waibel FW, Meyer DC, Gerber $\mathrm{C}$, et al. Efficacy of standardized training on a virtual reality simulator to advance knee and shoulder arthroscopic motor skills. BMC Musculoskelet Disord 2018; 19(1): 150. https://doi. org/10.1186/s12891-018-2072-0.

32. Yari SS, Jandhyala CK, Sharareh B, Athiviraham A, Shybut TB. Efficacy of a virtual arthroscopic simulator for orthopaedic surgery residents by year in training. Orthop J Sports Med 2018; 6(11): 2325967118810176. https://doi.org/10.1177/2325 967118810176.

33. Gustafsson A, Pedersen P, Rømer TB, Viberg B, Palm H, Konge L. Hip-fracture osteosynthesis training: exploring learning curves and setting proficiency standards. Acta Orthop 2019; 90(4): 348-353. https://doi.org/10.1080/17453674.2019. 1607111.

34. Hooper J, Tsiridis E, Feng JE, Schwarzkopf R, Waren D, Long WJ, et al. Virtual reality simulation facilitates resident training in total hip arthroplasty: a randomized controlled trial. J Arthroplasty 2019; 34(10): 2278-2283. https://doi.org/10. 1016/j.arth.2019.04.002.

35. Rölfing JD, Nørskov JK, Paltved C, Konge L, Andersen SAW. Failure affects subjective estimates of cognitive load through a negative carry-over effect in virtual reality simulation of hip fracture surgery. Adv Simul 2019; 4(1): 1-8. https://doi.org/10. 1186/s41077-019-0114-9.
36. Lohre R, Bois AJ, Athwal GS, Goel DP, Canadian Shoulder and Elbow Society (CSES). Improved complex skill acquisition by immersive virtual reality training: a randomized controlled trial. J Bone Joint Surg Am 2020; 102(6): e26. https://doi. org/10.2106/JBJS.19.00982.

37. Walbron P, Common H, Thomazeau H, Sirveaux F. Evaluation of arthroscopic skills with a virtual reality simulator in first-year orthopaedic residents. Int Orthop (SICOT) 2020; 44: 821-827. https://doi.org/10.1007/s00264020-04520-1.

38. Walbron P, Common H, Thomazeau H, Hosseini K, Peduzzi L, Bulaid Y, et al. Virtual reality simulator improves the acquisition of basic arthroscopy skills in first-year orthopedic surgery residents. Orthop Traumatol Surg Res 2020; 106(4): 717724. https://doi.org/10.1016/j.otsr.2020.03.009.

39. Xin B, Huang X, Wan W, Lv K, Hu Y, Wang J, et al. The efficacy of immersive virtual reality surgical simulator training for pedicle screw placement: a randomized double-blind controlled trial. Int Orthop 2020; 44(5): 927-934. https://doi. org/10.1007/s00264-020-04488-y.

40. Mabrey JD, Reinig KD, Cannon WD. Virtual reality in orthopaedics: is it a reality? Clin Orthop Relat Res 2010; 468(10): 2586-2591. https://doi.org/10.1007/s11999-010-1426-1.

41. Vaughan N, Dubey VN, Wainwright TW, Middleton RG. A review of virtual reality based training simulators for orthopaedic surgery. Med Eng Phys 2016; 38(2): 59-71. https://doi. org/10.1016/j.medengphy.2015.11.021.

42. Pfandler M, Lazarovici M, Stefan P, Wucherer P, Weigl M. Virtual reality-based simulators for spine surgery: a systematic review. Spine J 2017; 17(9): 1352-1363. https://doi.org/10. 1016/j.spinee.2017.05.016.

43. Bartlett J, Lawrence J, Stewart M, Nakano N, Khanduja V. Does virtual reality simulation have a role in training trauma and orthopaedic surgeons? Bone Joint J 2018; 100(5): 559-565. https://doi.org/10.1302/0301-620X.100B5. BJJ-2017-1439.

44. Fritz T, Stachel N, Braun BJ. Evidence in surgical training-a review. Innov Surg Sci 2019; 4(1): 7-13. https://doi.org/10. 1515/iss-2018-0026.

45. Hedman LR, Felländer-Tsai L. Simulation-based skills training in non-performing orthopedic surgeons: skills acquisition, motivation, and flow during the COVID-19 pandemic. Acta Orthop 2020; 91(5): 520-522. https://doi.org/10.1080/ 17453674.2020.1781413.

46. Negrillo-Cárdenas J, Jiménez-Pérez JR, Feito FR. The role of virtual and augmented reality in orthopedic trauma surgery: from diagnosis to rehabilitation. Comput Methods Programs Biomed 2020; 191: 105407. https://doi.org/10.1016/j.cmpb. 2020.105407.

47. Lee GI, Lee MR. Can a virtual reality surgical simulation training provide a self-driven and mentor-free skills learning? Investigation of the practical influence of the performance 
metrics from the virtual reality robotic surgery simulator on the skill learning and associated cognitive workloads. Surg Endosc 2018; 32(1): 62-72. https://doi.org/10.1007/s00464017-5634-6.

48. Boyle E, O'Keeffe DA, Naughton PA, Hill AD, McDonnell $\mathrm{CO}$, Moneley D. The importance of expert feedback during endovascular simulator training. J Vasc Surg 2011; 54(1): 240248.e1. https://doi.org/10.1016/j.jvs.2011.01.058.

49. Johns BD. The creation and validation of an augmented reality orthopaedic drilling simulator for surgical training. $\mathrm{PhD}$ thesis, University of Iowa; 2014. https://doi.org/10.17077/etd. x8t4uged. 